\title{
Diversification, Diseconomies of Scope, and Vertical Contracting: Evidence from the Taxicab Industry
}

\author{
Evan Rawley \\ The Wharton School, University of Pennsylvania, Philadelphia, Pennsylvania 19104, rawley@wharton.upenn.edu
}

Timothy S. Simcoe

Boston University School of Management, Boston, Massachusetts 02215, tsimcoe@bu.edu

\begin{abstract}
$\mathrm{T}^{\mathrm{h}}$ his paper studies how firms reorganize following diversification, proposing that firms use outsourcing, or vertical disintegration, to manage diseconomies of scope. We also consider the origins of scope diseconomies, showing how different underlying mechanisms generate contrasting predictions about the link between withinfirm task heterogeneity and the incentive to outsource following diversification. We test these propositions using microdata on taxicab and limousine fleets from the Economic Census. The results show that taxicab firms outsource, by shifting the composition of their fleets toward owner-operator drivers, when they diversify into the limousine business. The magnitude of the shift toward driver ownership is larger in less urban markets, where the tasks performed by taxicab and limousine drivers are more similar. These findings suggest that (1) firms use outsourcing to manage diseconomies of scope at a particular point in the value chain and (2) interagent conflicts can be an important source of scope diseconomies.
\end{abstract}

Key words: diversification; diseconomies of scope; adaptation; outsourcing; asset ownership

History: Received April 24, 2008; accepted April 28, 2010, by Bruno Cassiman, business strategy. Published online in Articles in Advance August 3, 2010.

\section{Introduction}

Why do firms become less efficient as they increase their scope of activities? Though scholars have proposed many answers to this puzzle, there is little empirical evidence on the origins of scope diseconomies. This paper develops a novel theoretical framework wherein scope diseconomies link the horizontal and vertical boundaries of the firm and use this framework to guide an empirical analysis of outsourcing, or vertical disintegration, in response to diversification. Our main finding is that diseconomies of scope cause diversifying firms to outsource formerly integrated activities that are costly to govern within a diversified enterprise.

By focusing on reorganization, this study departs from an established literature on diversification and performance, which asks whether related expansion outperforms conglomerate diversification (Wernerfelt and Montgomery 1988, Lang and Stulz 1994). Because firm performance could be either a cause or a consequence of diversification, the prior literature has produced a vigorous debate over selection effects and whether diversification is a managerial mistake (Villalonga 2004). Instead of analyzing performance effects, we study the link between diversification and organizational change-specifically outsourcing-to learn about the underlying factors that link firm scope to governance costs.
Our theoretical framework builds on Coase (1937) and Williamson (1975) by assuming that firms outsource, or vertically disintegrate, when the costs of integration exceed the costs of using markets or longterm contracts to govern a transaction. However, we link outsourcing to diversification by suggesting that coordinating activities across multiple divisions can increase the cost of governing a particular transaction or activity within the firm. Our framework suggests that firms will diversify and outsource when diversification creates net benefits to the firm, but governance costs associated with diversification and vertical integration exceed the legacy transaction-cost benefits of vertical integration. Figure 1 depicts the overarching logic: scope diseconomies are caused by transaction or activity-level inefficiencies that lead firms to rethink their vertical boundaries following diversification.

We draw on three broad theories of corporate governance to explain why internal governance costs increase with firm scope. First, diversification may exacerbate monitoring costs that arise from cognitive limitations (Penrose 1959, Schoar 2002) or incomplete information (Holmstrom 1979). Second, diversification may increase influence costs, which arise when divisions engage in wasteful rent-seeking competition (Milgrom 1988, Rajan et al. 2000) or fail to coordinate because of conflicting incentives (Bresnahan et al. 2009, Zhou 2010). Third, diversification may increase 
Figure 1 Diversification and Outsourcing

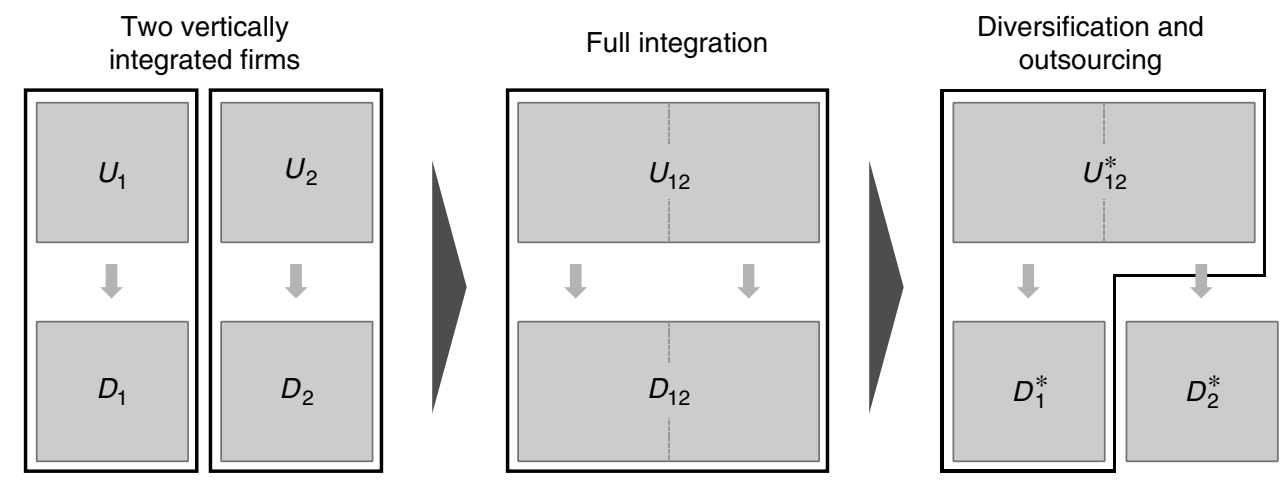

Upstream economies of scope: $\pi\left(U_{12}^{*}\right)>\pi\left(U_{1}\right)+\pi\left(U_{2}\right)$

Downstream diseconomies of scope: $\pi\left(D_{12}\right)<\pi\left(D_{1}^{*}\right)+\pi\left(D_{2}^{*}\right)$
Key:

$\square=$ Firm boundaries $\square=$ Activities
$\forall=$ Transactions
$U=$ Upstream $\quad D=$ Downstream

social comparison costs when employees in a multidivisional firm perceive differences in the compensation or promotion practices of a new division to be unfair (Fehr and Schmidt 1999, Nickerson and Zenger 2008).

Our first hypothesis predicts that when diversification produces transaction or activity-level diseconomies of scope, firms will respond by outsourcing. Outsourcing reduces monitoring, influence, and envy costs by altering the nature of the supply relationship. Specifically, outsourcing relaxes constraints on managerial attention by substituting market incentives for direct monitoring. By shifting decision rights to a new entity and allowing the market to set prices, outsourcing replaces the influence costs of bureaucratic rent-seeking with the armslength bargaining and renegotiation costs that attend a contractual relationship. And by moving employees outside the boundary of the firm, outsourcing limits within-firm heterogeneity in incentives, abilities, and rewards, thereby reducing envy and social comparison costs.

Our second hypothesis predicts that the mediating effect of task diversity (i.e., the variation in a firm's physical or intellectual production processes) on the link between diversification and outsourcing depends on the underlying source of scope diseconomies. In particular, we identify competing predictions that emerge from two broad yet distinct theoretical mechanisms, which we refer to as principal-agent and interagent governance problems. Principal-agent problems emphasize conflict between employees at different levels in a formal hierarchy, whereas interagent theories focus on conflict between peers. Thus, monitoring costs are primarily a principal-agent problem, social comparison costs are primarily an interagent problem, and influence cost models combine the two mechanisms.

Principal-agent theories predict that the marginal costs of diversification are increasing in task diversity, because it is harder to monitor and manage more heterogeneous divisions. Conditional on diversification, principal-agent theories predict more outsourcing as functional differences between formerly independent lines of business increase. Interagent theories generate the opposite prediction. For instance, social comparison costs increase when agents in different divisions perform similar tasks but receive different incentives and rewards, leading to feelings of envy (Kulik and Ambrose 1992, Festinger 1954). Thus, conditional on diversification, interagent theories predict less outsourcing as functional differences between divisions increase. We test the competing predictions of principal-agent and interagent theories by measuring the relationship between diversification and outsourcing under conditions of high and low task diversity.

Our empirical setting is the taxicab and limousine industry. ${ }^{1}$ This industry is well suited to study diversification, diseconomies of scope, and outsourcing for several reasons. First, entry deregulation in the limousine market led to a wave of diversification during the early 1990s. We use prederegulation variation in

\footnotetext{
${ }^{1}$ We use the term "limousine" to describe vehicles that are often called black cars, town cars, sedans, or executive limousines. These vehicles are distinct from "prom" or stretch limousines. Because we exploit variation across many distinct local markets, this paper could also be thought of as a study of hundreds of similar taxicab and limousine industries.
} 
local market conditions as an instrument for the postderegulation incentive to diversify. Second, vertical integration, measured in terms of fleet versus driver ownership of taxicabs, exhibits considerable variation both within and between fleets. Although we cannot measure governance costs directly in our setting, our firm-level analysis uses a continuous dependent variable of vertical integration, which allows us to measure outsourcing at an unusual level of detail. Third, differences in local market size provide a meaningful measure of task differentiation between taxicabs and limousines. In particular, limousines are prohibited from servicing the "street hail" spot market, which is a significant revenue source for taxicabs in urban markets but is less important in nonurban markets. We exploit the sharp difference between diversified firms in urban and nonurban environments to measure the mediating effect of task differentiation on the link between diversification and outsourcing. Finally, because diversified fleets are a relatively simple example of the multiproduct firm, this setting limits unobserved heterogeneity in outputs, prices, incentives, and internal organization that might otherwise bias empirical tests.

Our baseline results show that diversifying firms outsource more intensively than firms that choose to remain focused. Specifically, diversifying firms outsource an additional $30 \%$ of the assets (i.e., taxicabs) in their legacy business compared to nondiversifiers. Moreover, conditional on diversification, the shift toward owner-operator drivers is less pronounced in markets where there is more task differentiation. Doubling the population density of a local market leads to an $11 \%$ reduction in outsourcing at a diversified firm, suggesting that interagent costs are the primary source of scope diseconomies in our empirical setting.

To provide additional context for the statistical results, we interviewed taxicab fleet managers, who suggested that although diversification creates substantial efficiencies, particularly in dispatching operations, diversifying firms faced considerable operational challenges when combining nonowner taxicab drivers with a more professional group of limousine drivers. These problems ranged from driver suspicion that fleets actively steer better rides to limousines, to reports of fistfights between taxicab and limousine drivers and incidents of ride "scooping," where taxi drivers raced to intercept limousine customers. Thus, managers of diversified fleets described a preference for contracting with owner-operator taxi drivers, whose skills and backgrounds more closely match limousine drivers' characteristics, making them easier to manage and a more appropriate source of spare capacity for the limousine segment. Together with the statistical evidence, our field interviews point toward social comparison costs as a key driver of scope diseconomies.

This study makes four main contributions to the literature on diversification and the scope of the firm. First, we show that outsourcing is an important organizational strategy for managing the increased governance costs associated with diversification. Thus, we connect the literature on the costs of diversification to a literature that emphasizes efficient organizational adaptation through resource redeployment and asset divestiture following diversification (Capron et al. 1998, Capron et al. 2001). ${ }^{2}$ Second, we show that interagent conflicts, in general, and social comparison costs, in particular, are an important source of scope diseconomies, using both qualitative evidence and a novel statistical test for discriminating between alternative sources of scope induced governance costs. Third, by linking changes in the horizontal and vertical boundaries of the firm, we take a small step toward integrating the literature on diversification as an organizational strategy (Teece 1980, Levinthal and $\mathrm{Wu} 2010$ ) with organizational economics' long-standing emphasis on buyer-supplier relations (Macher and Richman 2008). By conceiving of the firm as a portfolio of transactions or routines, as in organizational economics, we call attention to the idea that diseconomies of scope at a specific point in the value chain will lead the firm to adapt organizationally by outsourcing a particular activity following diversification. Finally, our main findings have a broader normative interpretation: diseconomies of scope at the transaction or activity level can make it difficult to manage parallel divisions with different priorities, processes, or incentive schemes, even (or perhaps especially) when operational and market similarities create aggregate economies of scope for the firm.

\section{Diseconomies of Scope, Diversification, and Outsourcing}

In this section, we explain why diseconomies of scope lead firms to reconsider their vertical boundaries following diversification. Our theory assumes that diversification is exogenous but rational: firms only diversify if they expect synergies to be greater than incremental costs. However, diversifying firms do more than simply combine operations. They also reorganize to minimize frictions or capture efficiencies created by the merger. Although reorganization might take a variety of forms, our theory emphasizes outsourcing, or vertical disintegration, as a way to

\footnotetext{
${ }^{2}$ For a review of the literature on the costs of diversification, see Montgomery (1994).
} 
manage increased governance costs. ${ }^{3}$ One of our key messages is that by studying the link between diversification and outsourcing, we can draw inferences about the size and nature of scope diseconomies. We begin by developing this broad idea, before describing the underlying causes of scope diseconomies and proposing a set of hypotheses.

Figure 1 provides a stylized illustration of our theoretical framework. In the figure, two vertically integrated firms merge and subsequently outsource the activities of one downstream division. Diversification is motivated by upstream economies of scope, whereas outsourcing alleviates increased governance costs created by combining downstream activities. The figure highlights several aspects of our theory. First, the unit of analysis is a group of related transactions or activities, and the objective is to choose boundaries and governance mechanisms that maximize total surplus. Second, we apply the term diseconomies of scope to any increase in a firm's internal governance costs caused by diversification. Thus, diversification can produce diseconomies of scope but still be rational, as long as it generates even greater synergies elsewhere. Finally, our framework links scope diseconomies to both transactions and activities, which are often omitted from studies of diversification and vertical integration, respectively.

The mechanism behind Figure 1 is straightforward. If diversification produces a larger increase in governance costs under vertical integration than under market or contractual governance, then the probability of outsourcing should increase. Put differently, diversifying firms will outsource formerly integrated activities that produce large negative spillovers across divisions. This argument is closely related to the familiar logic of transaction cost analysis. Empirical tests of transaction cost economics typically assume that internal governance costs are fixed and look for a positive correlation between outsourcing and asset specificity. We take the opposite approach of assuming the costs of market governance are fixed-or at least uncorrelated with diversification-and interpreting a positive correlation between diversification and outsourcing as evidence of increased internal governance costs. ${ }^{4}$ This idea can be formalized, as we

\footnotetext{
${ }^{3}$ Outsourcing does not imply that payments flow in a particular direction. For example, a firm might outsource upstream manufacturing operations (in which case it would pay for the inputs) or a downstream sales force (in which case it would be paid for the outputs).

${ }^{4}$ Assuming that the costs of market or contractual governance are fixed with respect to a change in scope is different from assuming that those costs are small. We could also make the weaker (but still sufficient) assumption that the marginal costs of diversification are larger under vertical integration than under outsourcing; however, see Gibbons $(2005, \S 3.2)$ for a critique of this approach.
}

show in the appendix, using a simplified version of Milgrom and Roberts's (1990) model of complementarities. ${ }^{5}$ However, to understand the deeper links between diversification and diseconomies of scope, we need to unpack the specific mechanisms that produce these added costs. The literature on firm governance suggests three different explanations for scope diseconomies: monitoring, rent-seeking, and envy.

Monitoring costs arise from centralized oversight of divisions and are the main focus of the literature on diversification. We conceptualize monitoring costs more broadly than simply bureaucratic costs, which will arise whether divisions are managed jointly or as separate firms. In particular, monitoring costs include the opportunity costs of using a common set of people and processes to manage a heterogeneous portfolio of businesses. Thus, diversification may increase monitoring costs if increased scope exacerbates the cognitive or informational constraints on corporate management. For example, one source of monitoring costs is managerial distraction, an idea that dates back at least to Penrose (1959). Her central argument is that a corporate manager's job is to monitor divisions, a task that grows more difficult with the number, size, and variety of business units. Because a manager's cognitive capacity is limited, increasing the scope or diversity of operations increases the probability that strategic decisions will be poorly adapted to the idiosyncratic needs of individual business units. Schoar (2002) provides empirical support for the managerial distraction hypothesis, finding that when manufacturing firms diversify into new segments the productivity of their existing plants tends to fall.

Incomplete information can also lead to monitoring costs. Since the early moral hazard models of Jensen and Meckling (1976) or Holmstrom (1979), many studies have examined how a corporate principal might optimally respond when the agent who runs a division takes hidden actions or holds private information. ${ }^{6}$ Solutions range from monitoring to incentive contracts to delegation and job design. However, a common thread is that incomplete information makes

\footnotetext{
${ }^{5}$ Diversification and outsourcing are complements if the marginal returns to outsourcing increase with scope. The appendix shows that the assumption of complementarity is both necessary and sufficient to produce Hypothesis 1. Moreover, when the marginal cost of diversification under market governance is zero, complementarity is formally equivalent to diseconomies of scope.

${ }^{6}$ Some authors would draw a conceptual distinction between monitoring costs and problems of moral hazard (hidden action) or adverse selection (hidden information). We group them to highlight the shared emphasis on costly information acquisition by an uninformed principal. Whereas similar informational problems may be a necessary condition in the envy and influence cost models described in this section, those theories place a greater focus on alternative mechanisms as the main source of governance costs.
} 
the agency relationship costly to manage. If the severity of the underlying information problem depends on the scope of a firm, then these principal-agent models yield a theory of scope diseconomies.

A second broad explanation for diseconomies of scope is that agents in a diversified firm waste resources seeking preferential treatment from the corporate center. For example, Milgrom and Roberts (1988) conceive of corporate politics as a rent-seeking process, where division-level agents take actions that are privately beneficial, but unproductive for the firm as a whole. Corporate managers seek policies that discourage these behaviors (e.g., through budgeting or transfer pricing), but a CEO's authority and lack of commitment power invites lobbying by divisions who hope to skew the rules of the game. Whereas the incomplete-information principal-agent problems previously described are often an important component of influence cost models, we place influence costs in a separate category because they emphasize interdivisional interactions and inefficiencies. In particular, rent-seeking incentives depend on both monitoring costs and the actions taken by agents in other divisions.

Rajan et al. (2000) develop an empirical test for influence costs in the capital budgeting process. They find that increased diversity, measured as variation in the asset-weighted Tobin's $q$ of a firm's divisions, is correlated with inefficient investment decisions. Specifically, firms invest more heavily in divisions with low values of Tobin's $q$. Their argument for indexing influence costs to diversity draws on the monitoring cost component of the theory: they assume that returns to lobbying increase as divisions grow more heterogeneous, because corporate managers are easier to mislead when they have a less comprehensive understanding of a division's operational activities. Bresnahan et al. (2009) use case study evidence to argue that influence seeking by managers of legacy businesses create scope diseconomies that hinder large incumbents' efforts to respond to major technological change.

Nickerson and Zenger (2008) develop a third theory of scope diseconomies that emphasizes employees' taste for fairness, as in Fehr and Schmidt (1999). They argue that variance in compensation tends to produce a group of agents who envy their better-paid peers and consequently engage in a variety of inefficient behaviors, including "reduced effort, (engaging in) influence activities, departure, noncooperativeness, or even outright sabotage" (p. 1431). This theory of interagent conflict builds upon research in social psychology (e.g., Festinger 1954, Adams 1965) that describes the origins of individual perceptions of inequity and highlights the importance of endogenous reference groups. Extending this earlier research, Kulik and
Ambrose (1992) suggest that firm boundaries are a natural point of reference for employees, who are much more sensitive to inequities within a firm than between firms. Furthermore, diversification integrates activities where both pay structures and pay levels are distinctly different, which provides fodder for envious feelings. Thus, by combining agents who perform similar tasks but have different compensation systems, incentives and ability levels, diversification can lead to increased envy across divisional lines and unproductive behavior by disgruntled employees.

We build on theories of monitoring, influence, and social comparison costs by linking governance costs to the scope of the firm. Our central proposition is that scope-induced governance costs are larger under vertical integration than under market or contractual governance. Specifically, outsourcing lowers managerial distraction costs by placing operating decisions in the hands of the (now independent) division, and reduces monitoring costs by shifting the basis of monitoring from behavioral inputs to contractible outputs. Outsourcing also mitigates influence costs by placing decision rights in the hands of an independent firm, thereby changing the game of internal lobbying into an arms-length negotiation. Finally, outsourcing shifts the nature of social comparison costs from within to between firms. If within-firm comparisons are more salient to agents than comparisons to a supplier or contractor, then outsourcing activities performed by agents at the extremes of the incentive or skill distributions will reduce the overall level of envy. Thus, by changing the nature of monitoring, influence, and social comparison costs, outsourcing alleviates increased governance costs associated with diversification at the activity or transaction level.

In summary, when diversification increases the costs of governing a bundle of related transactions internally, firms will rethink vertical boundary choices that were efficient beforehand. Our first hypothesis, therefore, predicts that when diseconomies of scope lead to increased managerial distraction, influence costs, or envy, firms will use outsourcing to reduce the overall costs of governing the diversified firm.

Hypothesis 1. In the presence of diseconomies of scope, horizontal diversification leads to vertical outsourcing.

Our second hypothesis examines contrasting predictions about the mediating effect of task diversity, or variation in a firm's physical or intellectual production processes. These competing predictions emerge from two broad mechanisms, which we refer to as principal-agent and interagent problems. Principalagent problems focus on conflicts between employees at different levels in a formal hierarchy, whereas interagent problems emphasize conflicts between peers. 
Principal-agent problems are rooted in the informational problems and cognitive limitations that prevent a corporate principal from exercising complete control over division-level agents. The basic principalagent problem appears in many theories. For example, the managerial distraction hypothesis holds that it is harder to monitor a more heterogeneous portfolio of businesses, and can be viewed as an effort to explain the costs of conglomerate diversification, which represents an extreme case of task diversity (Penrose 1959, Schoar 2002). Monitoring cost theories grounded in hidden action problems will generate the same prediction if one assumes that increasing task diversity leads to weaker signals of division-level performance (Holmstrom 1979, 1982). Similarly, because task diversity places corporate managers at an informational disadvantage, it may increase division managers' rentseeking incentives in a model of influence costs. All of these examples focus on interactions between a corporate principal and a division-level agent, and stipulate that a principal's job grows more difficult as agentlevel task diversity increases.

In practice, managers often rely on information systems and business processes to address principalagent problems and extend their span of control. However, the efficacy of shared systems and controls typically declines with task diversity, because standardized management tools are often poorly suited to the idiosyncratic needs of individual divisions. Thus, when diseconomies of scope are caused by principalagent problems, the marginal costs of diversification will increase with task diversity, leading to a stronger link between diversification and outsourcing.

Interagent problems arise from conflicts between division-level peers and represent a second broad source of scope diseconomies. Conflicts between agents are typically rooted in resource congestion problems or perceived inequities in the distribution of opportunities and rewards. Because task similarity leads to increased resource sharing and greater salience of interdivisional comparisons, interagent conflicts are typically more severe when firms maintain operationally similar activities in different divisions.

To illustrate the link between interagent problems and task diversity, consider the case of envy and social comparison costs. If fully dissimilar tasks are rarely viewed as salient references, then increasing task differentiation should reduce the likelihood that workers will make interagent comparisons (Kulik and Ambrose 1992). Nickerson and Zenger (2008, p. 1434) observe that the saliency of envy increases with "spatial proximity, degree of interaction, and availability of information" to a reference group, where spatial proximity is broadly defined to include measures of social difference and contextualized measures of variation in ability (Festinger 1954). To the extent that lower task differentiation increases spatial proximity by narrowing the range of social differences and ability levels, while integration increases worker interaction and availability of information, social comparisons will naturally be more salient among employees who perform similar tasks within the same firm. Thus, for example, we might expect more enmity between investment and commercial bankers who both underwrite corporate debt than between a sales force with strong incentives and the employees of a manufacturing division.

Well-designed corporate policies (e.g., compensation, promotion, transfer-pricing, or capital budgeting) can mitigate interagent problems. However, these policies typically have limitations. Firms will be reluctant to address perceived inequity through a large pay increase for one group of employees, or to adjust incentives when there are large differences in the marginal product of seemingly similar tasks performed in different divisions. Conflicts over inherently scarce resources, such as top management positions, can be very hard to resolve. Thus, when diseconomies of scope are caused by interagent problems, task diversity reduces the marginal costs of diversification, leading to a weaker link between diversification and outsourcing.

We have argued that task diversity has different implications for the governance costs associated with principal-agent versus interagent problems. Specifically, if the correlation between diversification and outsourcing is stronger when task differentiation is high, the evidence suggests that principal-agent problems are the primary cause of scope diseconomies. If the link between diversification and outsourcing is stronger when task differentiation is low, the evidence points toward interagent problems. Because the two mechanisms generate opposing predictions, we test their relative strength as a pair of competing hypotheses:

Hypothesis 2A. When diseconomies of scope are caused by principal-agent conflicts, the impact of diversification on outsourcing will increase with task differentiation.

Hypothesis 2B. When diseconomies of scope are caused by interagent conflicts, the impact of diversification on outsourcing will decrease with task differentiation.

We conclude with a caveat. Our simple story of diversification and outsourcing holds all other aspects of the firm's organization constant. In general, diversifying firms might adapt their organization in a variety of ways, and these adaptations could interact in complex ways. For instance, Eccles (1985) describes how firms use transfer-pricing policies to 
ration scarce resources, prevent free-riding, and promote a sense of fairness. Shin and Stulz (1998) study capital budgeting and coordination. To address interagent conflicts, firms might redesign their promotion and compensation policies. Rather than work toward an omnibus theory that predicts when and how much each component of a firm's internal governance structure will respond to diversification, we focus on a single margin-outsourcing-and seek an appropriate setting to test our hypotheses.

\section{Taxicab and Limousine Industry}

Our empirical setting is the private-for-hire vehicle industry, or taxicab and limousine fleets. This industry provides a unique opportunity to study diversification and outsourcing for several reasons. First, in response to a wave of deregulation, many taxicab fleets diversified into the limousine market during the early 1990s. We show that a taxicab fleet's propensity to diversify is linked to concentration levels in the local limousine market, and we use that variation in initial market conditions as a source of exogenous variation in the incentive to diversify. Second, a ubiquitous regulatory requirement that limousine rides be prearranged produces a clear demarcation between the two market segments. As a result taxicab and limousine drivers dress differently, are trained differently, and are compensated differently even though they perform very similar tasks. Although the distinctions between taxicab and limousine drivers might be subtle to passengers, our interviews revealed that they are deeply significant to drivers within the industry, with compensation differences being a particularly divisive issue. We argue that task diversity is higher for diversified fleets in dense urban markets, where taxicabs earn a greater share of revenue from hails, as opposed to prearranged trips. Third, because there is relatively little asset specificity between drivers and firms, it is reasonable to assume that diversification does not change the costs of transacting between drivers and fleets through the market, but it does alter the cost of organizing the same relationship through a firm. This section describes the industry in greater detail, focusing on the legal factors that led to a diversification wave between 1992 and 1997 and the economic factors that influence the decision to diversify into limousines and contract with owner-operator taxicab drivers.

Taxicab and limousine markets are highly regulated. The number of taxicab licenses granted in a given market is typically fixed by a local taxicab commission, which provides medallions, or permits, that are associated with a specific vehicle. In most markets, these regulators also set prices and coordinate regular inspections. Entry into the limousine segment is considerably more flexible, and restrictions on the number of vehicles in use are rare. However, whereas taxicabs can legally accept spot market hails from any passenger who solicits a ride, all limousine rides must be prearranged through a centralized dispatcher.

The exclusion of limousines from the hail segment leads to some important differences in the organization of taxicab and limousine fleets. For example, taxicab drivers typically have stronger incentives than limousine drivers. A study by the Transit Cooperative Research Program (Gilbert et al. 2002) found that 50\% of limousine drivers are paid a fixed hourly wage and $35 \%$ share a large portion of each trip's revenue with the firm, whereas $90 \%$ of cab drivers are full residual claimants; they pay a flat fee to the dispatcher and keep all of their gross receipts. This arrangement gives diversified firms a strong incentive to allocate their most lucrative rides to limousines. When firms favor limousines over taxicabs, this contributes to a sense of alienation felt by taxicab drivers (Sheahan and Smith 2003).

There are two basic types of driver in the taxicab segment: shift drivers and owner operators. Shift drivers lease cars, permits, and dispatching services from a fleet. In 1990, 51\% of the vehicles in U.S. taxicab fleets were staffed via day or half-day leases (Taxicab, Limousine \& Paratransit Association 1990). The same survey suggests that roughly one-third of the vehicles in U.S. taxicab fleets are leased on a weekly or monthly basis. Owner operators are drivers who have purchased a vehicle and medallion, and are free to choose whether to contract with a fleet for dispatching services.

Interestingly, vehicle ownership does little to change a taxicab driver's short-term incentive to locate rides, because both fleet drivers and owner operators are typically full residual claimants. However, owning a taxicab and medallion may solve moral hazard problems or promote long-term investments to acquire industry-specific knowledge. Given the benefits of using owner operators, the level of fleet ownership in the taxicab segment is at first puzzling (Schneider 2010). However, many shift drivers are recent immigrants with very few marketable skills, who would find it difficult to finance a car and medallion, which can cost over $\$ 300,000$ (Luo 2004).

Before the early 1990s, the taxicab and limousine segments were kept separate through regulation. This situation changed in the early 1990s, following a series of legal challenges to local regulatory authority. One of the most famous examples was the 1993 "Freedom Cab" case (Jones v. Temmer) in Denver, where a small firm challenged Colorado's broad regulatory authority over entry into the taxicab market (Cox 1993). Within four years of the Freedom Cab case, most cities (or states) had deregulated entry into 
the limousine segment. The practical result of these changes was to remove any legal or political obstacles to cross-ownership, which led to a broad wave of diversification. In our data, $54 \%$ of the taxicab fleets that survived from 1992 to 1997 diversified into limousines during that period (see Table 1).

The logic behind diversification into the limousine segment is predicated on fixed cost sharing and cross-selling. Although opportunities for cost sharing extend to a wide range of activities-from servicing vehicles to negotiating group rates for insuranceshared marketing and dispatch operations present the greatest opportunity. However, our discussions with fleet managers suggest that conflicts over shared dispatching also create significant organizational challenges for the firm. In some cases, taxicab drivers scoop limousine dispatches by arriving in advance of the limousine and giving customers the mistaken impression that their limousine had been cancelled. Other firms reported that taxicab drivers had vandalized limousines and threatened limousine drivers during shift changes, accusing limousine drivers of skimming the best rides. At a minimum, integration creates confusion among shift drivers over contract terms, engendering ill will between taxicab and limousine drivers. ${ }^{7}$

Although the leasing system allows fleets to tap a large low-skilled labor pool, managing shift drivers, who are only weakly committed to their job, was described as a major challenge, particularly in diversified firms. Shift drivers are often characterized as having limited knowledge of the city, poor language skills, and exhibit strong tendencies to engage in antisocial behavior. Owner operators, by contrast, are characterized as professionals with an intricate knowledge of their city, who are fluent English speakers, keep their vehicle clean and in good operating condition, drive safely, and give the impression that they take pride in their work.

Our field research suggests that outsourcing is a common organizational strategy to reduce diseconomies of scope that arise from social conflicts between taxicab and limousine drivers in a diversified fleet. Fleet managers invoke the difficulty of integrating shift (taxicab) drivers with limousine drivers as a major reason for contracting with (taxicab) owner operators. Because owner operators more readily understand the quid pro quo inherent in their contract with a diversified fleet, there is a reduced chance of conflict between drivers. Moreover, owneroperators' investments in market-specific knowledge makes them less reliant on the dispatcher than are

\footnotetext{
${ }^{7}$ Taxicab drivers in diversified firms pay lower lease prices because they receive fewer and less attractive dispatches, but this is often not well understood by the shift drivers.
}

Table 1 Descriptive Statistics

\begin{tabular}{|c|c|c|c|c|}
\hline \multirow[b]{2}{*}{ Test sample $(n=560)$} & \multicolumn{2}{|c|}{1992} & \multicolumn{2}{|c|}{1997} \\
\hline & Mean & Std. dev. & Mean & Std. dev. \\
\hline FLEETOWN & 0.86 & 0.33 & 0.63 & 0.36 \\
\hline DIVERSIFY & 0.00 & 0.00 & 0.54 & 0.50 \\
\hline Taxicab revenue $(\$ 000)$ & 675 & 1,890 & 849 & 2,739 \\
\hline Taxicab capital $(\$ 000)$ & 230 & 673 & 319 & 934 \\
\hline Total taxicabs & 24 & 64 & 35 & 83 \\
\hline Fleets with 2 taxicabs & 0.27 & 0.44 & 0.09 & 0.29 \\
\hline Fleets with 3-5 taxicabs & 0.19 & 0.39 & 0.22 & 0.42 \\
\hline Fleets with 6-10 taxicabs & 0.19 & 0.39 & 0.20 & 0.40 \\
\hline Fleets with 11-25 taxicabs & 0.17 & 0.38 & 0.21 & 0.40 \\
\hline Fleets with 26-50 taxicabs & 0.09 & 0.29 & 0.10 & 0.30 \\
\hline Fleets with > 50 taxicabs & 0.10 & 0.30 & 0.17 & 0.38 \\
\hline Taxicabs in the county & 231 & 480 & 474 & 673 \\
\hline Limousines in the county & 103 & 228 & 221 & 414 \\
\hline CONCENTRATION & 0.05 & 0.13 & 0.32 & 0.36 \\
\hline County population (000) & 885 & 1,036 & 985 & 1,147 \\
\hline County square miles & 861 & 1642 & 878 & 1,714 \\
\hline URBAN & 0.37 & 0.48 & 0.36 & 0.48 \\
\hline Partnership & 0.02 & 0.13 & 0.02 & 0.15 \\
\hline Corporation & 0.80 & 0.40 & 0.80 & 0.40 \\
\hline All firms & \multicolumn{2}{|c|}{ Total 1992} & \multicolumn{2}{|c|}{ Total 1997} \\
\hline Taxicab revenue (\$M) & \multicolumn{2}{|c|}{521} & \multicolumn{2}{|c|}{669} \\
\hline Number of taxicabs & \multicolumn{2}{|c|}{20,014} & \multicolumn{2}{|c|}{29,960} \\
\hline Number of fleet owned taxicabs & \multicolumn{2}{|c|}{16,426} & \multicolumn{2}{|c|}{18,303} \\
\hline Number of fleets & \multicolumn{2}{|c|}{1,020} & \multicolumn{2}{|c|}{1,106} \\
\hline
\end{tabular}

shift drivers and, therefore, less likely to subvert the dispatching system through scooping. Taken together, the professionalism and knowledge of owner operators serves to simplify the dispatching system, which alleviates some of the managerial problems associated with an integrated taxicab and limousine business, particularly interagent conflicts that arise due to envious feelings between taxicab drivers and limousine drivers.

\section{Data and Measurement}

We use data from the 1992 and 1997 Economic Census of Transportation and Warehousing, which includes every taxicab (SIC 412100) and limousine (SIC 411920) firm in the United States with at least one employee. These data contain establishment-level information on line of business revenue at the six-digit industry level, number of vehicles by type (taxicab versus limousine) and geographic identifiers. We focus on taxicab fleets with at least two taxicabs, $\$ 10,000$ of taxicab revenue and at least one other taxicab fleet in their market (county). ${ }^{8}$ The 1992 and 1997 Economic Censuses contain 1,020 and 1,106 fleets, respectively, that meet these criteria. ${ }^{9}$ Our panel regressions are

\footnotetext{
${ }^{8}$ Alternative samples did not change the results presented below.

${ }^{9}$ We discard very small establishments that the Census imputes values for, rather than surveying directly.
} 
based on a set of 560 fleets that reported complete data in both years. Table 1 presents descriptive statistics for these fleets, which account for over $70 \%$ of industry revenue and approximately two-thirds of all vehicles.

Our dependent variable FLEETOWN is the share of all taxicabs owned by the fleet, which is equal to the number of taxicabs owned by the fleet, divided by the total number of taxicabs operated by the fleet. Table 1 shows that the mean fleet-ownership rate fell from $86 \%$ in 1992 to $63 \%$ in 1997 . We measure diversification using an indicator variable DIVERSIFY that equals zero for taxicab fleets with no limousines, and one for taxicab fleets with one or more limousines in their fleet. ${ }^{10}$

We use county-level population density as a proxy for task differentiation between the taxicab and limousine segments in a diversified fleet. In dense urban markets where street-hails account for a substantial share of all taxi-related revenue, taxicabs and limousines follow different processes to locate and service rides. In particular, limousines are only dispatched to prearranged rides whereas taxicabs frequently locate spot market rides by cruising or queuing in taxicab stands. In less urban markets, where most rides are dispatched through the same central switchboard, task differentiation between the taxicab and limousine segments is low: limousines are essentially taxicabs painted black. We exploit this empirical regularity to construct two proxies for task differentiation between taxicabs and limousines. First, we use the log of 1992 county population per square mile (DENSITY) as a continuous measure of task differentiation. Second, we construct an easy-to-interpret indicator variable (URBAN) that equals one for fleets located in counties with population density above 4,000 people per square mile. ${ }^{11}$

Table 1 shows a large increase in the total number of taxicabs in our sample between 1992 and 1997. The increase reflects the fact that many formerly independent owner operators chose to contract with taxicab fleets during this time period, partly in response to increased competition following entry deregulation in the limousine segment. ${ }^{12}$ Our theory predicts that these owner operators will seek to join fleets that have diversified into the limousine segment because the match between an owner operator and a diversified

\footnotetext{
${ }^{10}$ Alternative measures of diversification, such as a threshold for the percentage of total revenue or capital in the limousine segment, yielded very similar results.

${ }^{11}$ This measure of URBAN is based on the average population density of the 1,000 largest cities (by population) in the United States during the last quarter of the twentieth century (Kim 2007).

${ }^{12}$ Independent drivers are only captured by the Economic Census when they contract with a fleet.
}

fleet creates more value than a match to a focused taxicab firm. This matching process suggests an implication of our hypotheses in terms of the evolution of firm-level capabilities: fleets that are vertically integrated and focused compete by minimizing capital investment in vehicles and managing a pool of lowskill drivers, whereas diversified and vertically disintegrated fleets compete by establishing a brand that attracts the high-quality rides valued by independent limousine and taxicab drivers.

\section{Empirical Strategy}

Our baseline specification is a linear regression in first differences. Let $i$ index the fleets in our sample and $\Delta$ represent the first-difference operator (between 1992 and 1997). To test Hypothesis 1, we regress $\triangle$ FLEETOWN on DIVERSIFY and a vector of control variables $X$ that might influence firms' assetownership decisions, including firm size measured by lagged dollar value of a firm's capital stock, changes in local market population, changes in the share of taxicabs owned by other firms in the same market; changes in the number of taxicabs in other firms in the market, changes in the number of limousines in other firms in the market, a dummy for fleets that register as a corporation, and a dummy for urban markets. ${ }^{13}$ Thus, our initial specification is

$$
\Delta \text { FLEETOWN }_{i}=\alpha+\beta \text { DIVERSIFY }_{i}+X_{i} \delta+\varepsilon_{i},
$$

where the parameter $\alpha$ measures the sample average change in FLEETOWN, and $\varepsilon$ is the unexplained portion of any changes in outsourcing. Because we only observe two time periods, taking first differences is similar to introducing firm fixed effects, as either approach controls for unobserved timeinvariant fleet-level factors that might influence the level of FLEETOWN.

Whereas (1) controls for correlation between diversification and time-invariant fleet-level unobservables that affect outsourcing, one still might be concerned about selection based on time-varying factors. In an experimental design, we would randomly assign diversification status and measure ex post differences in fleet asset ownership across the treatment and control groups. In practice, we observe changes in both diversification and asset ownership following a regulatory shift that creates new opportunities for expansion into related markets. In this setting, we might expect diversifiers to be those fleets that will benefit most from expanding, which could confound our estimates. For example, if fleets that experience a positive productivity shock expand through both

\footnotetext{
${ }^{13}$ Similar results were obtained using models with a full set of legal form of organization dummies.
} 
diversification into limousines and increased contracting with owner operators, the coefficient on DIVERSIFY will be biased.

We address the potential endogeneity of diversification by using the lagged concentration of limousines in a given county (CONCENTRATION) as an instrument for DIVERSIFY. Industry observers suggest that diversification is less attractive when there are strong limousine incumbents that have already developed deep relationships in the lucrative corporate segment. High limousine concentration also represents an entry barrier because of the increased threat of retaliation. ${ }^{14}$ Therefore, CONCENTRATION should be uncorrelated with factors in the error term that influence taxicab fleets' outsourcing decisions and negatively correlated with the probability of diversification following deregulation.

To complement our instrumental variables analysis, we use propensity score methods (Rosenbaum and Rubin 1983) to control for selection bias. Specifically, we estimate a probit model of the decision to diversify and use fitted values from that model as estimates of the propensity score $\operatorname{Prob}\left(D_{\text {IVERSIFY }}=1 \mid X_{i}\right)$. We then drop all fleets that do not fall on the common support of the estimated propensity score distribution, and we weight the included observations by the inverse probability of treatment to balance the treatment and control groups (Imbens 2004). Compared to the standard approach of adding controls to a linear regression, the propensity score methodology makes fewer functional form assumptions and eliminates the influence of noncomparable control and treatment group observations that are off the common support of the estimated propensity score distribution. ${ }^{15}$

\footnotetext{
${ }^{14}$ Our instrumental variables identification strategy would not be valid if ex ante limousine concentration were correlated with factors that influence the relationship between taxicab fleets and drivers in local markets. However, the cross-sectional correlation between FLEETOWN and CONCENTRATION was not significant (raw correlation of 0.04), and our informal discussions suggest that the primary factor limiting entry in the limousine market was access to a base of corporate customers. Another concern might be that the timing or nature of deregulation is correlated with both ex ante limousine concentration and factors that influence FLEETOWN. However, our discussions with local regulators suggest that deregulation was often carried out at the state level with little concern for variation in local market conditions. Finally, a practical drawback of our instrumental variable is that it only generates market-level variation; we could not identify any fleet-level shifters of the costs or benefits of diversification that would satisfy the exclusion restriction for an instrument. However, we find that our IV generates substantial between-fleet variation in practice, because the 560 fleets in our balanced panel operate in hundreds of different local markets.

${ }^{15}$ Intuitively, this approach will outperform standard regression control methods when the response of FLEETOWN to DIVERSIFY varies with $X$ (i.e., there is treatment heterogeneity), and $X$ is correlated with DIVERSIFY.
}

Table 2 presents estimates from the probit model that we use to estimate the propensity score: column (1) reports coefficients and column (2) reports marginal effects at the average value of each regressor. Only firm size, population density, and limousines per capita had a statistically significant effect on the diversification decision. Columns (3)-(8) in Table 2 compare the sample means of $X$ for diversifying and nondiversifying fleets, in both the full and matched samples. Although the percentage of differences are typically small, they are statistically significant for several variables, and trimming the sample produces only a modest improvement. This suggests that using propensity score weights is appropriate; though we do not expect large changes in the coefficient estimate on DIVERSIFY given the modest explanatory power of our first stage results.

We test Hypotheses 2A and 2B by adding a proxy for task differentiation (DENSITY) and the interaction between DENSITY and DIVERSIFY to our baseline specification (1) yielding

$$
\begin{aligned}
\Delta \text { FLEETOWN }_{i}= & \alpha+\beta_{1} \operatorname{DIVERSIFY~}_{i}+\beta_{2} \operatorname{DENSITY}_{i} \\
& +\beta_{3}\left(\text { DIVERSIFY }_{i} \times \operatorname{DENSITY~}_{i}\right) \\
& +X_{i} \delta+\varepsilon_{i} .
\end{aligned}
$$

For ease of interpretation and to ensure that our results are not driven by outliers in the DENSITY distribution, we also estimate an alternative specification where DENSITY is replaced with the binary measure URBAN.

The potential endogeneity of DIVERSIFY remains our key identification concern in model (2). Fortunately, our proxies for task differentiation, DENSITY and $U R B A N$, are exogenous to the dependent variable $\triangle F L E E T O W N$, in that they are not choice variables: firms choose where to locate before learning that the possibility of diversification exists. Moreover, the key coefficient in model (2) is based on a triple difference: $\beta_{3}$ measures how the difference in outsourcing between focused and diversified fleets changes over time in more or less urban markets. Thus, timeinvariant firm or market-level factors that might be correlated with outsourcing are absorbed by first differencing, and the main effect of density $\left(\beta_{2}\right)$ controls for any difference in outsourcing trends between urban and nonurban markets from 1992 to 1997. In principle, we could instrument for the interaction term by interacting DENSITY with CONCENTRA$T I O N$, but this approach performed poorly in practice. Because we fail to reject null hypothesis that DIVERSIFY is exogenous in model (1), our estimates of model (2) are based on a simple linear regression. 
Probit Model of Diversification from Taxicabs to Limousines

Dependent variable: Diversified from taxicabs to limousines between 1992 and $1997\{0,1\}$

\begin{tabular}{|c|c|c|c|c|c|c|c|c|}
\hline & \multirow[b]{2}{*}{$\begin{array}{c}(1) \\
\text { Coef. } \\
\end{array}$} & \multirow[b]{2}{*}{$\begin{array}{c}(2) \\
\partial y / \partial u \text { at } \overline{\mathbf{u}} \\
\end{array}$} & \multicolumn{3}{|c|}{ Full sample } & \multicolumn{3}{|c|}{ Common support } \\
\hline & & & $\begin{array}{l}(3) \\
\text { Focus }\end{array}$ & $\begin{array}{c}(4) \\
\text { Diversified }\end{array}$ & $\begin{array}{c}(5) \\
t \text {-test on } \Delta\end{array}$ & $\begin{array}{l}(6) \\
\text { Focus }\end{array}$ & $\begin{array}{c}(7) \\
\text { Diversified }\end{array}$ & $\begin{array}{c}(8) \\
t \text {-test on } \Delta\end{array}$ \\
\hline $\begin{array}{l}1992 \text { total factor } \\
\text { productivity }\end{array}$ & $\begin{array}{r}-0.05 \\
(0.09)\end{array}$ & $\begin{array}{c}-0.02 \\
(0.03)\end{array}$ & $\begin{array}{c}0.11 \\
(0.05)\end{array}$ & $\begin{array}{r}-0.00 \\
(0.04)\end{array}$ & 1.98 & $\begin{array}{c}0.02 \\
(0.05)\end{array}$ & $\begin{array}{c}-0.02 \\
(0.04)\end{array}$ & 0.54 \\
\hline $\begin{array}{c}1992 \text { Fleet taxicab } \\
\text { ownership rate }\end{array}$ & $\begin{array}{c}0.17 \\
(0.22)\end{array}$ & $\begin{array}{c}0.07 \\
(0.09)\end{array}$ & $\begin{array}{c}0.89 \\
(0.02)\end{array}$ & $\begin{array}{c}0.83 \\
(0.02)\end{array}$ & 1.95 & $\begin{array}{c}0.88 \\
(0.02)\end{array}$ & $\begin{array}{c}0.83 \\
(0.02)\end{array}$ & 1.65 \\
\hline $1992 \log$ (taxicab capital) & $\begin{array}{r}-0.86 \\
(0.52)\end{array}$ & $\begin{array}{r}-0.34^{*} \\
(0.21)\end{array}$ & $\begin{array}{l}4.75 \\
(0.09)\end{array}$ & $\begin{array}{l}3.93 \\
(0.07)\end{array}$ & 7.42 & $\begin{array}{c}4.34 \\
(0.07)\end{array}$ & $\begin{array}{c}3.82 \\
(0.06)\end{array}$ & 5.25 \\
\hline $1992 \log ($ taxicab capital²) & $\begin{array}{c}0.02 \\
(0.02)\end{array}$ & $\begin{array}{c}0.01 \\
(0.01)\end{array}$ & $\begin{array}{c}9.50 \\
(0.21)\end{array}$ & $\begin{array}{l}7.86 \\
(0.15)\end{array}$ & 6.35 & $\begin{array}{l}8.68 \\
(0.20)\end{array}$ & $\begin{array}{l}7.64 \\
(0.14)\end{array}$ & 4.26 \\
\hline Partnership & $\begin{array}{r}-0.37 \\
(0.46)\end{array}$ & $\begin{array}{c}-0.15 \\
(0.18)\end{array}$ & $\begin{array}{c}0.03 \\
(0.02)\end{array}$ & $\begin{array}{c}0.01 \\
(0.03)\end{array}$ & 0.56 & $\begin{array}{c}0.02 \\
(0.02)\end{array}$ & $\begin{array}{c}0.01 \\
(0.02)\end{array}$ & 0.36 \\
\hline Corporation & $\begin{array}{c}0.20 \\
(0.16)\end{array}$ & $\begin{array}{c}0.08 \\
(0.06)\end{array}$ & $\begin{array}{c}0.80 \\
(0.03)\end{array}$ & $\begin{array}{c}0.81 \\
(0.02)\end{array}$ & -0.24 & $\begin{array}{c}0.79 \\
(0.03)\end{array}$ & $\begin{array}{c}0.81 \\
(0.02)\end{array}$ & -0.64 \\
\hline $1992 \log ($ county pop.) & $\begin{array}{c}0.11 \\
(0.11)\end{array}$ & $\begin{array}{c}0.04 \\
(0.04)\end{array}$ & $\begin{array}{l}12.88 \\
(0.09)\end{array}$ & $\begin{array}{l}12.86 \\
(0.09)\end{array}$ & 0.19 & $\begin{array}{l}12.71 \\
(0.10)\end{array}$ & $\begin{array}{l}12.84 \\
(0.09)\end{array}$ & -1.02 \\
\hline $1992 \log \left(\right.$ county pop..$\left.^{2}\right)$ & $\begin{array}{l}0.00 \\
(0.00)\end{array}$ & $\begin{array}{c}0.00 \\
(0.00)\end{array}$ & $\begin{array}{l}6.15 \\
(0.08)\end{array}$ & $\begin{array}{l}5.73 \\
(0.08)\end{array}$ & 3.67 & $\begin{array}{l}6.06 \\
(0.09)\end{array}$ & $\begin{array}{l}5.71 \\
(0.08)\end{array}$ & 3.02 \\
\hline $\log \left(\right.$ county miles $\left.{ }^{2}\right)$ & $\begin{array}{c}-0.11 \\
(0.06)\end{array}$ & $\begin{array}{r}-0.04^{*} \\
(0.02)\end{array}$ & $\begin{array}{c}3.14 \\
(0.22)\end{array}$ & $\begin{array}{c}2.85 \\
(0.18)\end{array}$ & 1.02 & $\begin{array}{c}3.13 \\
(0.21)\end{array}$ & $\begin{array}{c}2.87 \\
(0.17)\end{array}$ & 0.96 \\
\hline $\left.\begin{array}{r}1992 \log (\text { taxicabs } \\
\text { in the county } \\
-i\end{array}\right)$ & $\begin{array}{r}-0.03 \\
(0.08)\end{array}$ & $\begin{array}{l}-0.01 \\
(0.03)\end{array}$ & $\begin{array}{l}2.18 \\
(0.10)\end{array}$ & $\begin{array}{l}1.70 \\
(0.09)\end{array}$ & 3.55 & $\begin{array}{l}2.05 \\
(0.11)\end{array}$ & $\begin{array}{l}1.71 \\
(0.10)\end{array}$ & 2.29 \\
\hline $\begin{array}{l}1992 \log \text { (limousines } \\
\text { in the county) }\end{array}$ & $\begin{array}{r}-0.16 \\
(0.06)\end{array}$ & $\begin{array}{l}-0.06^{* * *} \\
(0.02)\end{array}$ & $\begin{array}{c}0.25 \\
(0.03)\end{array}$ & $\begin{array}{c}0.34 \\
(0.03)\end{array}$ & -2.27 & $\begin{array}{c}0.23 \\
(0.03)\end{array}$ & $\begin{array}{c}0.35 \\
(0.03)\end{array}$ & -2.83 \\
\hline Urban & $\begin{array}{c}0.07 \\
(0.26)\end{array}$ & $\begin{array}{c}0.03 \\
(0.10)\end{array}$ & $\begin{array}{c}0.43 \\
(0.08)\end{array}$ & $\begin{array}{c}0.61 \\
(0.10)\end{array}$ & -1.41 & $\begin{array}{c}0.44 \\
(0.08)\end{array}$ & $\begin{array}{c}0.60 \\
(0.09)\end{array}$ & -1.33 \\
\hline Constant & $\begin{array}{c}0.28 \\
(1.05)\end{array}$ & $\begin{array}{c}0.03 \\
(0.10)\end{array}$ & & & & & & \\
\hline $\begin{array}{l}\text { Pseudo } R^{2} \\
N\end{array}$ & $\begin{array}{l}0.09 \\
560\end{array}$ & & 254 & 306 & & 213 & 292 & \\
\hline
\end{tabular}

*Significant at the $10 \%$ level; ${ }^{* *}$ significant at the $5 \%$ level; ${ }^{* * *}$ significant at the $1 \%$ level.

\section{Results}

Figure 2 foreshadows our main result by showing that there is a strong correlation between DIVERSIFY and changes in FLEETOWN. Moreover, this correlation does not appear to be driven by heterogeneity in fleet size, which might be the case if both diversification and increased use of owner operators were correlated with unobserved productivity shocks. Figure 3 illustrates our second key result: the link between diversification and changes in FLEETOWN is much stronger in nonurban markets.

Table 3 presents our baseline regressions, which show the impact of diversification into the limousine market on the asset-ownership mix of a taxicab fleet. We estimate four different versions of Equation (1): OLS, firm fixed effects, propensity score weighted regression, and the instrumental variables analysis (2SLS). Column (1) contains the baseline OLS results. The average change in the fleet vehicle ownership rate for diversifiers relative to focused incumbents is estimated to be negative $31 \%$, and this effect is significant at the $1 \%$ level. This estimate suggests that diversification accounts for roughly half of the large secular shift toward driver-owned cabs shown in Table 1.

Column (2) in Table 3 presents estimates from the traditional within estimator, in part to show that they are not substantially different from our preferred firstdifferences specification. In column (3), we report estimates from the propensity score model, which are indistinguishable from those produced by OLS. ${ }^{16}$

Because the decision to diversify is endogenous, the results shown in columns (1)-(3) can only be interpreted as correlations. In column (4), we present estimates from our 2SLS instrumental variables model, which controls for the potential endogeneity of DIVERSIFY by using CONCENTRATION as an instrumental variable. The first-stage relationship between limousine-market concentration and

\footnotetext{
${ }^{16}$ We also obtained similar results on changes in limousine ownership in limousine firms that diversified into taxicabs.
} 
Figure 2 Diversification and Asset Ownership (FLEETOWN) by Firm Size
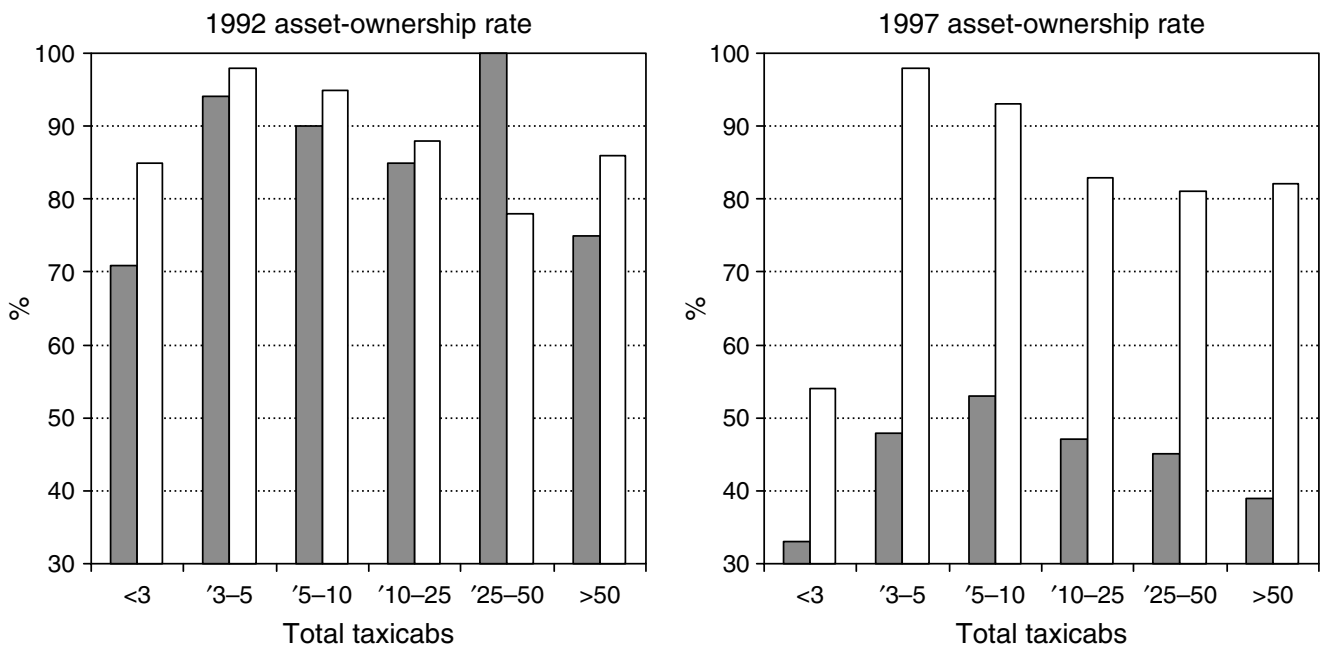

Firms that diversify 1992-1997 $(n=305)$

Firms that do not diversify 1992-1997 $(n=255)$

diversification is strongly negative: the $t$-statistic on CONCENTRATION in an OLS regression is -5.4 and the first-stage $F$-statistic of 11 indicates a powerful instrument. In the second stage, the estimated change in the fleet vehicle ownership rate is negative $50 \%$, which is statistically significant at the $1 \%$ level. We interpret this result as evidence of a causal relationship between diversification and changes in firm asset-ownership rates in this industry. Whereas the 2SLS point estimate is larger than the OLS estimate in column (1), they are not statistically different. Collectively, the findings in Table 3 strongly suggest that firms outsource to avoid the scope-induced governance costs associated with diversification.
Table 4 presents tests of our second hypothesis, based on Equation (2). We are particularly interested in the coefficient on the interaction between DIVERSIFY and URBAN, our proxy for task differentiation across divisions. Because our dependent variable is based on fleet ownership, a negative coefficient would provide evidence of outsourcing in response to principal-agent problems, whereas a positive coefficient would point toward interagent problems.

Column (1) in Table 4 shows the OLS result, where task differentiation is measured using the categorical variable URBAN. The main effect of diversification continues to be large, negative, and strongly statistically significant, with a point estimate of

Figure 3 Diversification and Asset Ownership (FLEETOWN) by Urban vs. Nonurban
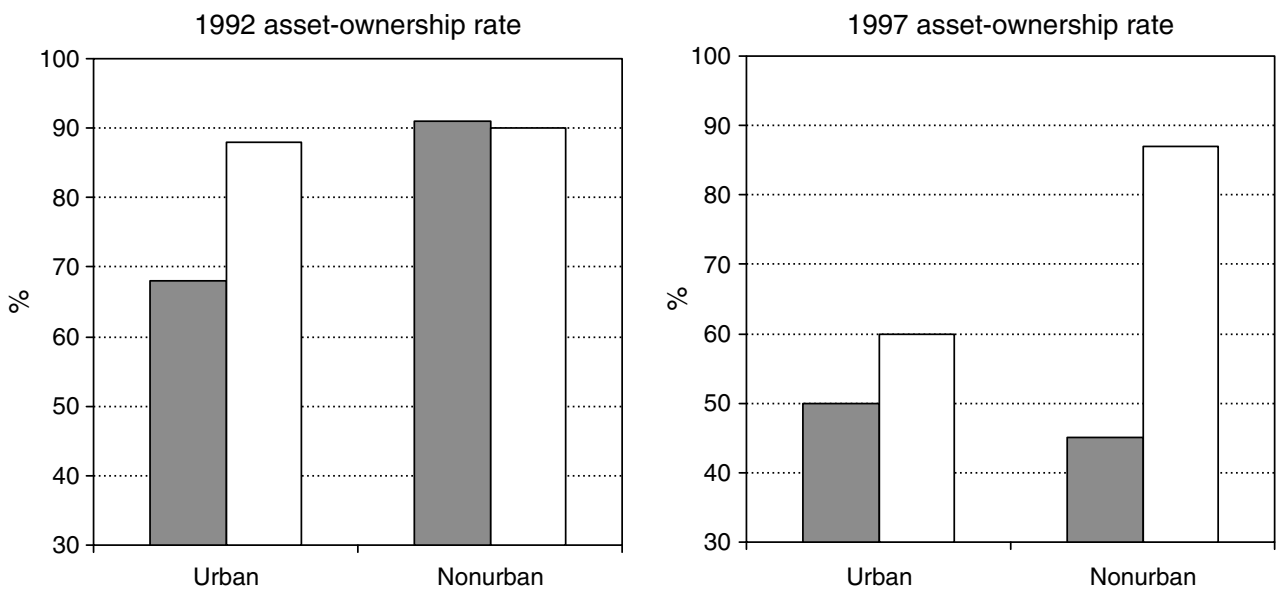

Firms that diversify 1992-1997 ( $n=305: 101$ urban, 204 nonurban)

Firms that do not diversify 1992-1997 ( $n=255: 56$ urban, 199 nonurban) 
Table 3

Diversification and Asset Ownership

Dependent variable: Change in the $\%$ of vehicles in the fleet owned by the firm $(\triangle F L E E T O W M)^{\text {a }}$

\begin{tabular}{|c|c|c|c|c|}
\hline & $\begin{array}{l}(1) \\
\text { OLS }\end{array}$ & $\begin{array}{l}(2) \\
\text { Fixed } \\
\text { effects }\end{array}$ & $\begin{array}{c}(3) \\
\text { Matched }\end{array}$ & $\begin{array}{c}(4) \\
2 S L S^{b}\end{array}$ \\
\hline DIVERSIFY & $\begin{array}{l}-0.31^{* * *} \\
(0.07)\end{array}$ & $\begin{array}{l}-0.40^{* * *} \\
(0.05)\end{array}$ & $\begin{array}{c}-0.27^{* *} \\
(0.11)\end{array}$ & $\begin{array}{l}-0.50^{* * *} \\
(0.09)\end{array}$ \\
\hline $1992 \log ($ taxicab capital) & $\begin{array}{l}-0.03 \\
(0.02)\end{array}$ & $\begin{array}{l}0.21^{* * *} \\
(0.05)\end{array}$ & $\begin{array}{r}-0.09^{*} \\
(0.05)\end{array}$ & $\begin{array}{r}-0.05^{*} \\
(0.03)\end{array}$ \\
\hline$\Delta$ County taxicab ownership rate ${ }_{-i}$ & $\begin{array}{r}0.09^{*} \\
(0.05)\end{array}$ & $\begin{array}{c}0.08 \\
(0.06)\end{array}$ & $\begin{array}{c}0.04 \\
(0.04)\end{array}$ & $\begin{array}{r}0.09^{*} \\
(0.05)\end{array}$ \\
\hline$\Delta \log \left(\right.$ taxicabs in the county $\left._{-i}\right)$ & $\begin{array}{l}0.03^{* *} \\
(0.02)\end{array}$ & $\begin{array}{r}-0.00 \\
(0.02)\end{array}$ & $\begin{array}{c}0.03 \\
(0.02)\end{array}$ & $\begin{array}{l}0.03^{* *} \\
(0.02)\end{array}$ \\
\hline$\Delta \log \left(\right.$ limousines in the county $\left.{ }_{-i}\right)$ & $\begin{array}{c}-0.02 \\
(0.02)\end{array}$ & $\begin{array}{c}0.02 \\
(0.02)\end{array}$ & $\begin{array}{c}-0.03 \\
(0.02)\end{array}$ & $\begin{array}{c}-0.02 \\
(0.02)\end{array}$ \\
\hline$\Delta \log ($ county pop.) & $\begin{array}{c}-0.13 \\
(0.15)\end{array}$ & $\begin{array}{r}-0.04 \\
(0.10)\end{array}$ & $\begin{array}{c}-0.12 \\
(0.19)\end{array}$ & $\begin{array}{c}-0.13 \\
(0.15)\end{array}$ \\
\hline Corporation & $\begin{array}{l}0.10^{* *} \\
(0.05)\end{array}$ & & $\begin{array}{l}0.11^{* *} \\
0.05\end{array}$ & $\begin{array}{l}0.12^{* *} \\
(0.05)\end{array}$ \\
\hline Urban & $\begin{array}{c}-0.05 \\
(0.07)\end{array}$ & & $\begin{array}{c}-0.09 \\
(0.11)\end{array}$ & $\begin{array}{c}-0.05 \\
(0.06)\end{array}$ \\
\hline Year dummy & & $\begin{array}{c}-0.02^{* *} \\
(0.01)\end{array}$ & & \\
\hline Constant & $\begin{array}{c}0.11 \\
(0.11)\end{array}$ & $\begin{array}{l}34.51^{* *} \\
(16.58)\end{array}$ & $\begin{array}{l}0.28 \\
(0.21)\end{array}$ & $\begin{array}{c}0.29 \\
(0.18)\end{array}$ \\
\hline 560 firm fixed effects & $\mathrm{N}$ & Y & $\mathrm{N}$ & $\mathrm{N}$ \\
\hline$R^{2} /$ Psuedo- $R^{2}$ & 0.12 & 0.23 & 0.09 & $\mathrm{n} / \mathrm{a}$ \\
\hline$N$ & 560 & 1,120 & 505 & 560 \\
\hline \multicolumn{5}{|c|}{ 2SLS first-stage summary statistics } \\
\hline $\begin{array}{l}F \text {-statistic } \\
t \text {-statistic on } \\
\text { CONCENTRATION } \\
\text { Adjusted } R^{2}\end{array}$ & & & & $\begin{array}{r}11 \\
-5.4\end{array}$ \\
\hline Adjusted $R^{2}$ & & & & 0.13 \\
\hline
\end{tabular}

Note. Standard errors are robust and clustered at the market (county) level, except in the fixed effect model where they are clustered at the firm level.

aln the fixed-effects model (column (2)), the dependent variable is FLEETOWN.

${ }^{\text {b First stage of the 2SLS model: } \triangle \text { DIVERSIFY }}{ }_{i}=\Gamma$ CONCENTRATION ${ }_{i 1992}+$ $\mathbf{X}_{i c} \gamma+\eta_{i}$. The Durbin-Wu-Hausman test rejects the null hypothesis that the instrument is not necessary at the $1 \%$ level $\left(\chi^{2}=20\right.$ in the 2SLS specification, column (4)).

*Significant at the $10 \%$ level; ** significant at the $5 \%$ level; *** significant at the $1 \%$ level.

negative $45 \%$. The point estimate on the interaction term is large and positive, at $55 \%$, and statistically significant at the $5 \%$ confidence level. Thus, we find that diversifying fleets are more likely to outsource if they operate in nonurban markets, where task differentiation between taxicabs and limousines is low.

Column (3) in Table 4 replaces the discrete measure URBAN with the continuous measure DENSITY, and finds similar results: doubling population density leads to an $11 \%$ increase in the impact of diversification on outsourcing. ${ }^{17}$ The models in columns (2) and (4) use propensity score matching to control for

\footnotetext{
${ }^{17}$ The same results were obtained with DENSITY winsorized at the first and ninety-ninth percentile.
}

Table 4 Diversification, Task Differentiation, and Asset Ownership

Dependent variable: Change in the $\%$ of vehicles in the fleet owned by the firm ( $\triangle F L E E T O W M)$

\begin{tabular}{|c|c|c|c|c|}
\hline & $\begin{array}{l}(1) \\
\text { OLS }\end{array}$ & $\begin{array}{c}(2) \\
\text { Matched }\end{array}$ & $\begin{array}{l}(3) \\
\text { OLS }\end{array}$ & $\begin{array}{c}(4) \\
\text { Matched }\end{array}$ \\
\hline DIVERSIFY & $\begin{array}{l}-0.45^{* * *} \\
(0.04)\end{array}$ & $\begin{array}{c}-0.46^{* * *} \\
(0.04)\end{array}$ & $\begin{array}{l}-1.03^{* * *} \\
(0.20)\end{array}$ & $\begin{array}{l}-1.11^{* * *} \\
(0.22)\end{array}$ \\
\hline DIVERSIFY $\times$ URBAN & $\begin{array}{l}0.55^{* *} \\
(0.17)\end{array}$ & $\begin{array}{l}0.57^{* * *} \\
(0.19)\end{array}$ & & \\
\hline URBAN & $\begin{array}{l}-0.20^{* *} \\
(0.09)\end{array}$ & $\begin{array}{c}-0.20^{* *} \\
(0.10)\end{array}$ & & \\
\hline $\begin{array}{l}\text { DIVERSIFY } \times \\
\text { LOG(1992 POP. DENSITY }\end{array}$ & & & $\begin{array}{l}0.11^{* * *} \\
(0.03)\end{array}$ & $\begin{array}{l}0.11^{* * *} \\
(0.04)\end{array}$ \\
\hline $\begin{array}{l}\text { LOG(1992 POPULATION } \\
\text { DENSITY) }\end{array}$ & & & $\begin{array}{r}-0.03^{*} \\
(0.02)\end{array}$ & $\begin{array}{r}-0.04^{*} \\
(0.02)\end{array}$ \\
\hline $1992 \log$ (taxicab capital) & $\begin{array}{c}-0.03 \\
(0.02)\end{array}$ & $\begin{array}{r}-0.08^{*} \\
(0.04)\end{array}$ & $\begin{array}{c}-0.03 \\
(0.02)\end{array}$ & $\begin{array}{r}-0.08^{*} \\
(0.04)\end{array}$ \\
\hline $\begin{array}{l}\Delta \text { County taxicab } \\
\text { ownership rate }\end{array}$ & $\begin{array}{c}0.06 \\
(0.05)\end{array}$ & $\begin{array}{c}0.07 \\
(0.05)\end{array}$ & $\begin{array}{c}0.06 \\
(0.05)\end{array}$ & $\begin{array}{r}0.08^{*} \\
(0.05)\end{array}$ \\
\hline$\Delta \log \left(\right.$ taxicabs in the county $\left.y_{-i}\right)$ & $\begin{array}{r}-0.00 \\
0.01\end{array}$ & $\begin{array}{l}-0.00 \\
(0.02)\end{array}$ & $\begin{array}{r}-0.00 \\
0.01\end{array}$ & $\begin{array}{l}-0.00 \\
(0.02)\end{array}$ \\
\hline $\begin{array}{l}\Delta \log (\text { limousines in the } \\
\left.\text { county }_{-i}\right)\end{array}$ & $\begin{array}{c}0.01 \\
(0.02)\end{array}$ & $\begin{array}{c}0.02 \\
(0.02)\end{array}$ & $\begin{array}{c}0.01 \\
(0.02)\end{array}$ & $\begin{array}{c}0.01 \\
(0.02)\end{array}$ \\
\hline$\Delta \log ($ county pop.) & $\begin{array}{r}-0.00 \\
(0.00)\end{array}$ & $\begin{array}{r}-0.00 \\
(0.01)\end{array}$ & $\begin{array}{r}-0.00 \\
(0.00)\end{array}$ & $\begin{array}{r}-0.00 \\
(0.00)\end{array}$ \\
\hline Corporation & $\begin{array}{l}0.10^{* *} \\
(0.05)\end{array}$ & $\begin{array}{l}0.11^{* *} \\
(0.05)\end{array}$ & $\begin{array}{l}0.10^{* *} \\
(0.05)\end{array}$ & $\begin{array}{l}0.11^{* *} \\
(0.05)\end{array}$ \\
\hline Constant & $\begin{array}{l}-0.14^{* *} \\
(0.06)\end{array}$ & $\begin{array}{c}-0.14 * * \\
(0.05)\end{array}$ & $\begin{array}{c}0.04 \\
(0.09)\end{array}$ & $\begin{array}{c}0.06 \\
(0.10)\end{array}$ \\
\hline$R^{2}$ & 0.18 & 0.18 & 0.18 & 0.18 \\
\hline$N$ & 560 & 505 & 560 & 505 \\
\hline
\end{tabular}

Note. Standard errors are robust and clustered at the market (county) level. *Significant at the $10 \%$ level; ** significant at the $5 \%$ level; ${ }^{* * *}$ significant at the $1 \%$ level.

ex ante observable differences between diversifiers and firms that remain focused. This also has little effect on the parameter estimates.

Overall, the results in Table 4 suggest that taxicab fleets outsource in response to interagent problems that lead to a positive correlation between task diversity and the marginal costs of diversification. ${ }^{18}$ This finding is consistent with our qualitative interview evidence, where fleet managers pointed out the importance of misunderstandings and conflicts between taxicab shift drivers and limousine drivers in a diversified firm.

\section{Conclusions}

This paper studies the mechanisms behind diseconomies of scope by examining how firms reorganize their vertical boundaries after diversifying. We show that changes in firm scope alter the marginal costs and benefits of vertical integration, leading firms

${ }^{18}$ We also replicated all of the results in this section using a Tobit specification (results are omitted). 
to rethink their vertical boundaries following diversification. We also investigate the mediating effect of task diversity on the diversification-outsourcing relationship, using it to discriminate between principalagent and interagent drivers of internal governance costs. A major challenge for empirical work on these questions is finding exogenous variation in the scope of the firm. To address that challenge, we exploit a unique opportunity, created by widespread diversification in response to entry deregulations in the taxicab and limousine industry, between 1992 and 1997.

Supporting our contention that diversification leads to outsourcing in the presence of diseconomies of scope, we find that diversifying taxicab fleets outsource extensively, deploying 30\% more owneroperator drivers than fleets who continue to focus only on the taxicab segment. Consistent with the idea that outsourcing helps alleviate interagent conflict, we find that the link between diversification and outsourcing is stronger in less urban markets, where task differentiation between taxicab and limousine drivers is less pronounced. Our interviews with taxicab fleet managers also suggest that envy-based interagent conflicts are an important source of scope diseconomies in this industry.

Of course, this study has several limitations. For instance, we do not measure governance costs directly. Thus, our interpretation of the link between diversification and outsourcing rests on the assumption that firm boundaries reflect the relative costs of alternative governance modes. A second limitation is our emphasis on a single organizational response. Although vertical boundaries have received a great deal of scholarly attention, firms could respond to diversification in a wide variety of ways. Thus, future research might usefully examine changes in compensation or promotion policies, transfer-pricing arrangements, or capital budgeting processes following a change in firm scope.

Despite these limitations, this paper presents new results, with implications for both corporate strategy and organizational economics. Whereas other studies have suggested that diversification can increase governance costs, this observation is rarely reconciled with the idea that firms make organizational changes following diversification to enhance efficiency. Indeed, the conceptual basis for diseconomies of scope is often predicated on systematic managerial mistakes. We develop a theoretical framework, based on efficient adaptation following diversification, and present evidence that firms' vertical boundaries respond to scope induced internal governance costs. Our findings also suggest that firms' horizontal and vertical boundaries are jointly determined in a predictable manner (Argyres and Liebeskind 1999).
For example, a vertically integrated manufacturing firm might find that efficient diversification requires the firm to outsource legacy raw material production processes that no longer "fit" with the diversified firm due to increased internal coordination costs in the procurement function. Thus, future research on how firms reorganize following diversification should consider the locus of scope diseconomies, as our research shows that diseconomies of scope at a specific point in the value chain can provide the impetus for ex post vertical disintegration. Whereas others have measured interdependencies across vertical supply relationships within a firm (Novak and Stern 2007, Forbes and Lederman 2009), we believe this is the first study to provide evidence of a similar link between the firm's horizontal and vertical boundaries.

The existence of complementarities between diversification and outsourcing also has ramifications for how scope diseconomies should be analyzed. Perhaps for analytical convenience, diseconomies of scope are often modeled as an increasing and convex function of the number of boundaries or divisions in a firm. Although this leads naturally to a simple analysis of optimal firm size, it provides little practical guidance in a world where complex interactions among activities or transactions in different divisions produce significant nonlinearities in the total cost of firm governance. Our findings highlight the importance of research that unpacks the interrelationships among divisions as a source of organizational diseconomies of scope.

Finally, we believe this work has normative implications for corporate strategy. In particular, we show that outsourcing is a tool corporate managers can use to manage increased governance costs that arise due to diseconomies of scope.

\section{Acknowledgments}

The authors thank Bronwyn Hall, Ron Jarmin, Mara Lederman, David Levine, Dan Levinthal, David Mowery, Frank Rothermael, Brian Silverman, Harbir Singh, Todd Zenger, the editors, two anonymous referees, and participants at the 2008 Brigham Young University-University of Utah Winter Strategy Conference and the 2008 Duke Strategy Conference and Academy of Management for helpful suggestions. The research in this paper was conducted while the authors were Census Bureau research associates at the California Census Research Data Center. Research results and conclusions expressed are the authors' and do not necessarily indicate concurrence by the Bureau of Census. This paper has been screened to ensure that no confidential data are revealed. The authors gratefully acknowledge funding support for this project from the Ewing Marion Kauffman Foundation and the Fisher Center for Real Estate and Urban Economics at the University of California, Berkeley's Haas School of Business. 


\section{Appendix. A Model of Diversification and Outsourcing}

This appendix develops a simple analytical framework that illustrates the link between diseconomies of scope, diversification, and outsourcing. Suppose there are two lines of business that could be horizontally integrated $(M=1)$ or managed as independent firms $(M=0)$. One line of business has a two-stage production process where downstream activities could be vertically integrated $(N=1)$ or outsourced $(N=0)$. For simplicity, the other line of business is always integrated, so there are two boundary decisions: one "vertical" and the other "horizontal." Joint expected profits are written as $\Pi(M, N)$.

To analyze outsourcing, we define the net benefits of vertical integration as a function of scope $V(M)=\Pi(M, 1)-$ $\Pi(M, 0)$, and an exogenous fixed cost $e_{v}$ that is only incurred under vertical integration. The probability of vertical integration is then $\operatorname{Pr}\left[V(M)>e_{v}\right]$, reflecting the Coasian (1937) logic that boundaries are determined by the relative cost of markets and hierarchies.

To analyze diversification, we define scope economies as a function of vertical integration $X(N)=\Pi(1, N)-\Pi(0, N)$. For fixed prices and quantities, $X(N)>0$ is equivalent to subadditivity of the cost function: a sufficient condition for mergers to be efficient (Baumol 1977, Evans and Heckman 1984). If diversified firms pay an exogenous fixed cost $e_{x}$, the probability of a merger is $\operatorname{Pr}\left[X(M)>e_{x}\right]$.

Many studies treat diversification and outsourcing as independent decisions. That would be true if both $V(M)$ and $X(N)$ were constant, so changes in firm scope have no impact on vertical integration (and vice versa). Figure A.1 illustrates this scenario, where firms cannot move from horizontally focused and vertically integrated $(M=0, N=1)$ to diversified and outsourced $(M=1, N=0)$ without changing both $V$ and $X$, or (equivalently) $e_{v}$ and $e_{x}$.

When diversification changes the net benefits of vertical integration, we say there are complementarities, defined as $D=X(0)-X(1)=V(0)-V(1)$. When $D=0$, both $X$ and $V$ must be constant, and we are back to the situation depicted in Figure A.1. When $D<0$, diversification lowers the returns to outsourcing. We focus on the case where $D>0$, so the benefits of outsourcing increase following diversification (perhaps because of increased conflicts at a particular stage of the production process, as discussed in the text).

When $D>0$, there is a straightforward link between diversification and outsourcing. Specifically, because $D>0$ implies that the net benefits of vertical integration are decreasing in scope, a switch from $M=0$ to $M=1$ must lower the probability of vertical integration. Figure A.2 illustrates the choice of firm boundaries when diversification and outsourcing are complements. Note that firms can move directly from horizontally focused and vertically integrated $(M=0, N=1)$ to diversified and outsourced $(M=1$, $N=0$ ) by crossing the diagonal line segment. We can use this cost benefit framework to state a more general version of Hypothesis 1. Specifically,

Hypothesis A.1. Diversification (increasing $M$ ) causes outsourcing (decreasing $N$ ) if and only if they are complements $(D>0)$.
Figure A.1 Independent Boundaries $(D=0)$

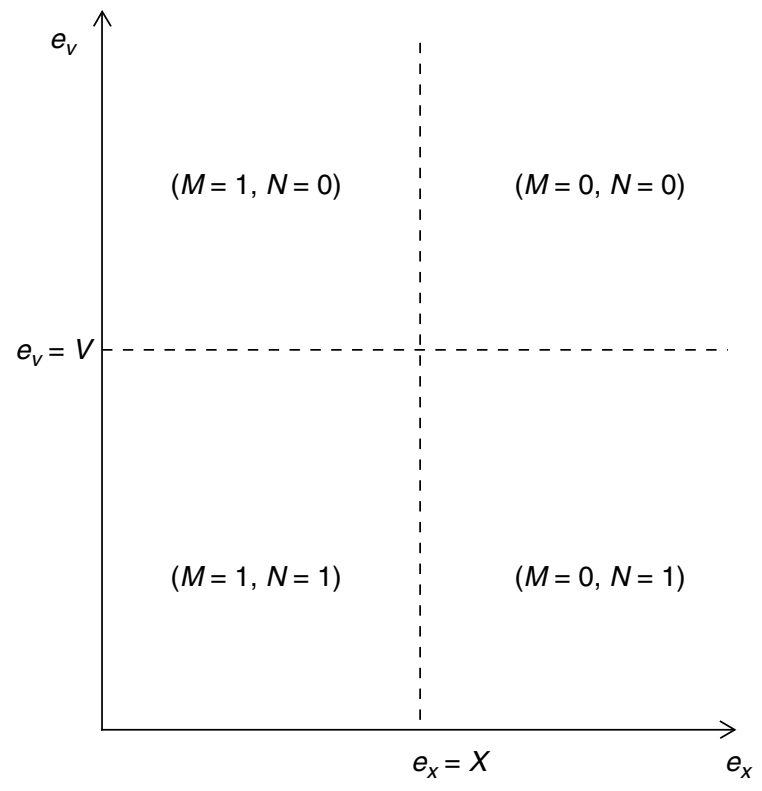

Proof. Diversification causes outsourcing $\Leftrightarrow \operatorname{Pr}[N=0 \mid$ $M=1]>\operatorname{Pr}[N=0 \mid M=0] \Leftrightarrow \operatorname{Pr}\left[V(1)<e_{v}\right]>\operatorname{Pr}[V(0)<$ $\left.e_{v}\right] \Leftrightarrow V(0)>V(1)$, since $V(M)$ is independent of $e_{v} \Leftrightarrow$ $D>0$.

To see the relationship between Hypothesis A.1 and diseconomies of scope, suppose that $X(N)$ can be separated into an upstream piece $X^{u}$ that does not depend on $N$, and a downstream part $X^{d}$ that does. Further, assume that diversification has no impact on (joint) downstream profits unless there is vertical integration, so that $\Pi^{d}(0,0)=\Pi^{d}(1,0)$ or equivalently $X^{d}(0)=0$. This implies that $D=X(0)-X(1)=$ $-X^{d}(1)=\Pi^{d}(0,1)-\Pi^{d}(1,1)$, which will be positive if and only if diversification reduces downstream profits under vertical integration. We refer to this reduction in expected profits from merging vertically integrated downstream divisions as diseconomies of scope.

Scope diseconomies are less general than complementarities. In particular, Hypothesis A.1 states that under very weak assumptions (i.e., boundary choices maximize П) our empirical results imply that diversification and outsourcing are complements. To interpret the same results as evidence of scope diseconomies, somewhat stronger assumptions are required; specifically, $X^{u}$ does not vary with $N$ and $X^{d}(0)=0$. Similar assumptions are standard in the empirical literature on buyer-supplier relationships, ${ }^{19}$ and we argue that they are reasonable in our empirical setting. Moreover, evidence of complementarities may be interesting in its own right (Argyres and Liebeskind 1999).

Because $D$ measures diseconomies of scope (the costs of merging integrated downstream divisions), our second hypothesis can be stated in terms of cost shifters. Suppose $Z$ is an index of task diversity. In the text, we argue that changing $Z$ has different implications for $D$ under different

${ }^{19}$ For example, to measure transaction costs, one typically assumes that asset specificity changes the costs of contracting without altering the costs of hierarchy. 


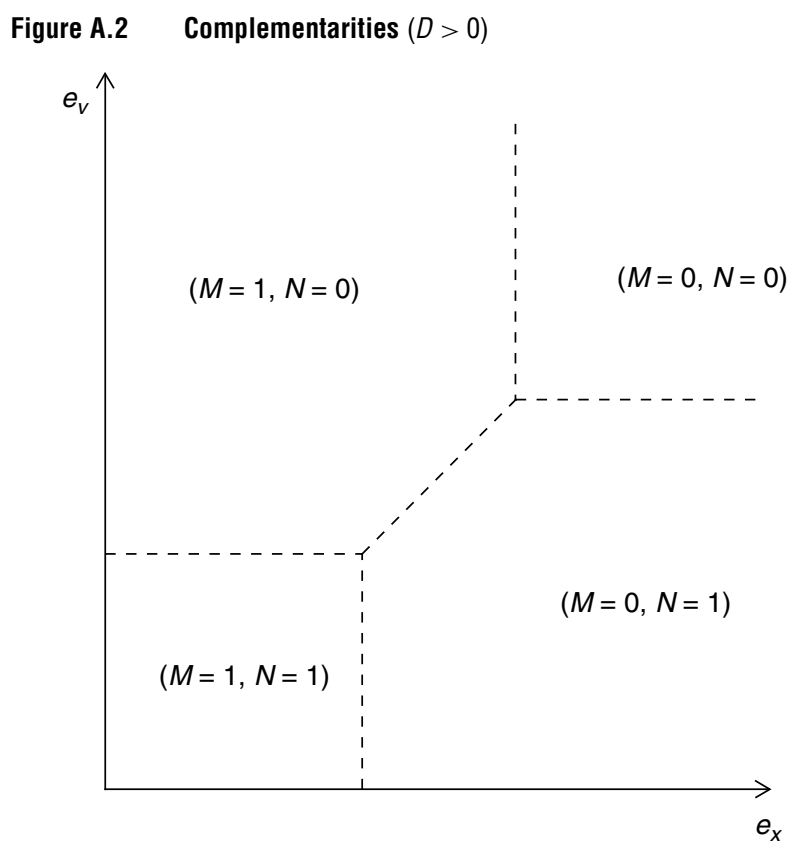

theories about the source of scope diseconomies. These predictions can be summarized as follows:

Нyротнеsis A.2A. Principal agent problems imply that $D(Z)$ is increasing in $\mathrm{Z}$.

Нyротнеsis A.2B. Interagent problems imply that $D(Z)$ is decreasing in $\mathrm{Z}$.

Before concluding, we offer two comments. First, Figures A.1 and A.2 highlight the importance of finding exogenous variation in $M$ for our empirical tests. In particular, when the unobserved $e_{x}$ and $e_{v}$ are negatively correlated, diversification and outsourcing will be positively correlated, even if $M$ and $N$ enter expected profits independently, as in Figure A.1. Thus, we can only test the hypothesis that $D>0$ by finding some source of variation in $M$ that is uncorrelated with these unobserved variables, and asking whether that variation also leads to a change in outsourcing.

Second, Milgrom and Roberts (1990) and Athey (1995) have shown how to generalize this simple cost-benefit framework to larger systems with many complementary business practices. Our assumption that $D>0$ corresponds to their concept of super-modularity or increasing differences in expected profitability. Unfortunately, more complex models can only deliver sharp predictions when all of the relevant business practices are pair-wise complementary, so the number of assumptions (or interaction terms in an empirical setting) grows very large as one moves toward corporate restructurings that involve many divisions, each with many vertical stages.

\section{References}

Adams, J. S. 1965. Inequity in social exchange. L. Berkowitz, ed. Advances in Experimental Social Psychology. Academic Press, New York, 267-299.

Argyres, N. S., J. P. Liebeskind. 1999. Contractual commitments, bargaining power, and governance inseparability:
Incorporating history into transaction cost theory. Acad. Management Rev. 24(1) 49-63.

Athey, S. 1995. Product and process flexibility in an innovative environment. RAND J. Econom. 26(4) 557-574.

Baumol, W. J. 1977. On the proper costs tests for natural monopoly in a multiproduct industry. Amer. Econom. Rev. 67(5) 809-822.

Bresnahan, T., S. Greenstein, R. Henderson. 2009. Schumpeterian competition and diseconomies of scope; illustrations from leading historical firms in computing. Working paper, Stanford University, Stanford, CA.

Capron, L., P. Dussauge, W. Mitchell. 1998. Resource redeployment following horizontal acquisitions in Europe and North America. Strategic Management J. 19(7) 631-661.

Capron, L., W. Mitchell, A. Swaminathan. 2001. Asset divestiture following horizontal acquisitions: A dynamic view. Strategic Management J. 22(9) 817-844.

Coase, R. H. 1937. The nature of the firm. Economica 4(16) 386-405.

Cox, G. D. 1993. Tackling taxis: First step? National Law J. 15(47) $1-3$.

Eccles, R. G. 1985. The Transfer Pricing Problem: A Theory for Practice. Lexington Books, New York.

Evans, D. S., J. J. Heckman. 1984. A test for subadditivity of the cost function with an application to the bell system. Amer. Econom. Rev. 74(4) 615-623.

Fehr, E., K. M. Schmidt. 1999. A theory of fairness, competition, and cooperation. Quart. J. Econom. 114(3) 817-868.

Festinger, L. 1954. A theory of social comparison processes. Human Relations 7(2) 117-140.

Forbes, S. J., M. Lederman. 2009. Adaptation and vertical integration in the airline industry. Amer. Econom. Rev. 99(5) 1831-1849.

Gibbons, R. 2005. Four formal(izable) theories of the firm? J. Econom. Behav. Organ. 58(2) 200-245.

Gilbert, G., T. J. Cook, A. Nalevanko, L. Everett-Lee. 2002. Transit Cooperative Research Program Report 75: The Role of the Private-forHire Vehicle Industry in Public Transit. National Academy Press, Washington, DC.

Holmstrom, B. 1979. Moral hazard and observability. Bell J. Econom. 10(1) 74-91.

Holmstrom, B. 1982. Moral hazard in teams. Bell J. Econom. 13(2) 324-340.

Imbens, G. 2004. Nonparametric estimation of average treatment effects under exogeneity: A review. Rev. Econom. Statist. 86(1) 4-29.

Jensen, M. C., W. H. Meckling. 1976. Theory of the firm: Managerial behavior, agency costs and ownership structure. J. Financial Econom. 3(4) 305-360.

Kim, S. 2007. Changes in the nature of urban spatial structure in the United States, 1890-2000. J. Regional Sci. 47(2) 273-287.

Kulik, C. T., M. L. Ambrose. 1992. Personal and situtational determinants of referent choice. Acad. Management Rev. 17(2) 212-237.

Lang, L. H. P., R. E. Stulz. 1994. Tobin's q, corporate diversification and firm performance. J. Political Econom. 102(6) 1248-1280.

Levinthal, D., X. Wu. 2010. Opportunity costs and non-scale free capabilities: Profit maximization, corporate scope, and profit margins. Strategic Management J. 31(7) 780-801.

Luo, M. 2004. Bids Exceed \$300,000 in Medallion Auction. New York Times (April 24) B2.

Macher, J. T., B. D. Richman. 2008. Transaction cost economics: An assessment of empirical research in the social sciences. Bus. Politics 10(1) 1-63.

Milgrom, P. 1988. Employment contracts, influence activities and efficient organization design. J. Political Econom. 96(1) $42-60$. 
Milgrom, P., J. Roberts. 1988. An economic approach to influence activities in organizations. Amer. J. Sociol. 94(Supplement) S154-S179.

Milgrom, P., J. Roberts. 1990. The economics of modern manufacturing: Technology, strategy and organization. Amer. Econom. Rev. 80(3) 511-28.

Montgomery, C. 1994. Corporate diversification. J. Econom. Perspect. 8(3) 163-178.

Nickerson, J. A., T. R. Zenger. 2008. Envy, comparison costs, and the economic theory of the firm. Strategic Management J. 29(13) $1429-1450$.

Novak, S., S. Stern. 2007. Complementarity among vertical integration decisions: Evidence from automobile product development. Management Sci. 55(2) 311-332.

Penrose, E. 1959. The Theory of the Growth of the Firm. John Wiley, New York.

Rajan, R., H. Servaes, L. Zingales. 2000. The cost of diversity: The diversification discount and inefficient investment. J. Finance 55(1) 35-80.

Rosenbaum, P. R., D. B. Rubin. 1983. The central role of the propensity score in observational studies for causal effects. Biometrika 70(1) 41-55.
Schneider, H. 2010. Moral hazard in leasing contracts: Evidence from the New York City taxi industry. J. Law Econom. Forthcoming.

Schoar, A. 2002. Effects of corporate diversification on productivity. J. Finance 57(2) 2379-2403.

Sheahan, M., P. Smith. 2003. Deviance and marginal occupations: The case of taxi drivers. Deviant Behav. 24(5) 449-466.

Shin, H., R. Stulz. 1998. Are internal capital markets efficient? Quart. J. Econom. 113(2) 531-552.

Taxicab, Limousine \& Paratransit Association (TLPA). 1990. Taxicab/ Paratransit Fact Book. TLPA, Kensington, MD.

Teece, D. J. 1980. Economies of scope and the scope of the enterprise. J. Econom. Behav. Organ. 1(3) 223-247.

Villalonga, B. 2004. Diversification discount or premium? New evidence from the business information tracking series. J. Finance 59(2) 479-506.

Wernerfelt, B., C. Montgomery. 1988. Tobin's $q$ and the importance of focus in firm performance. Amer. Econom. Rev. 78(1) 246-250.

Williamson, O. E. 1975. Markets and Hierarchies: Analysis and Antitrust Implications. Free Press, New York.

Zhou, Y. M. 2010. Synergy, coordination costs and diversification choices. Strategic Management J. Forthcoming. 